\title{
KHASIAT MADU MENURUNKAN TEKANAN DARAH DAN HEMATOLOGI PARAMETER
}

\author{
Efficacy of Honey to Lower Blood Pressure and \\ Hematological Parameters
}

\author{
Nurhaedar Jafar, Sitti Khadijah Hamid, Citrakesumasari, Ulfa Najamuddin, \\ Aminuddin Syam \\ Jurusan Ilmu Gizi Fakultas Kesehatan Masyarakat Universitas Hasanuddin \\ (eda_jafar@yahoo.co.id)
}

\begin{abstract}
ABSTRAK
Angka kejadian Diabetes Melitus (DM) terus mengalami peningkatan, baik di dunia, regional, maupun di Indonesia. Salah satu penyebab DM adalah stres oksidatif, sehingga madu sebagai antioksidan alami mampu menurunkan komplikasi yang terjadi. Penelitian ini bertujuan menilai efek pemberian madu terhadap tekanan darah dan hematologi parameter. Jenis rancangan yang digunakan adalah quasi experiment dengan desain prepost control. Populasi adalah penderita DM tipe 2 di dua wilayah kerja puskesmas di Kota Makassar. Sampel adalah sebagian yang memenuhi kriteria inklusi sebanyak 36 penderita DM tipe 2 yaitu 18 responden kelompok intervensi (KI) (diberikan madu dan edukasi gizi), dan 18 responden kelompok kontrol (KII) (diberikan edukasi gizi). Analisis data menggunakan uji Wilcoxon dan uji Mann-Whitney U. Hasil penelitian yaitu terjadi penurunan signifikan kadar kolesterol total, LDL, Gula Darah Puasa (GDP) dan Tekanan Darah Diastolik (TDD) pada KI. KII terjadi penurunan signifikan pada kadar LDL dan GDP, tetapi terjadi peningkatan signifikan pada TDD. Terjadi perbedaan yang signifikan pada TDD antara KI dengan KII $(\mathrm{p}=0,04)$. Pemberian madu memberi perubahan positif pada GDP (26,2\%), total kolesterol $(8,3 \%)$, LDL (11,7\%), HDL (5,4\%), tekanan darah sistolik (TDS) (4,1\%) dan TDD $(9,1 \%)$. Kesimpulan dari penelitian bahwa madu menurunkan kadar GDP, kolesterol total, LDL, TDD dan TDS pada penderita DM tipe 2 .
\end{abstract}

Kata kunci : Madu, diabetes melitus, hematologi

\section{ABSTRACT}

The incidence of diabetes mellitus is increasing both globally, regionally and in Indonesia. One cause of diabetes is oxidative stress, making honey as a natural antioxidant able to reduce complications. This study aimed to assess the effect of honey on blood pressure and hematological parameters. The design is kind of quasiexperimental design with pre-post control. The population was patients with type 2 diabetes mellitus in two working areas health centers in the city of Makassar. Samples were some who met the inclusion criteria were 36 patients with type 2 diabetes are 18 respondents intervention group (KI) (given honey and nutrition education), and 18 respondents control group (KII) (given nutrition education). Data analysis using the Wilcoxon test and Mann-Whitney U. The results are significant decline in total cholesterol, LDL cholesterol, fasting blood glucose (FBG) and diastolic blood pressure (DBP) at KI. KII significant decrease in LDL levels and FBG, but a significant increase in the DBP. There was significant difference in the DBP between KI KII $(p=0,04)$. Giving honey to give a positive change in $F B G(26,2 \%)$, total cholesterol (8,3\%), LDL (11,7\%), HDL (5,4\%), systolic blood pressure $(S D B)(4,1 \%)$ and $D B P(9,1 \%)$. The conclusion that honey lowers $F B G$, total cholesterol, $L D L, D B P$ and $S D B$ in patients with type 2 diabetes mellitus.

Keywords: Honey, diabetes mellitus, hematologi 


\section{PENDAHULUAN}

Badan kesehatan dunia World Heath Organization (WHO), tahun 2013 melaporkan bahwa lebih dari $80 \%$ kematian akibat Diabetes Mellitus (DM) terjadi di negara berpendapatan rendah-menengah. ${ }^{1}$ Hal ini juga ditunjukkan pada wilayah Asia bahwa yang mengalami diabetes $13,2 \%$ menjadi $5,5 \%$ dalam 3 tahun. ${ }^{2}$ Indonesia, menurut WHO tahun 2012, merupakan negara ke dua terbesar setelah India yang mempunyai penderita DM terbanyak yaitu 8.426 .000 orang di tingkat Asia Tenggara, dan diperkirakan meningkat menjadi 21.257.000 pada tahun 2030. ${ }^{3}$ Hasil Riset Kesehatan Dasar (Riskesdas) tahun 2007 melaporkan proporsi penyebab kematian akibat DM pada kelompok usia 45-54 tahun di daerah perkotaan menempati peringkat ke dua yaitu $14,7 \%$ dan untuk daerah pedesaan menempati rangking ke enam yaitu 5,8\%. Tahun 2011 Indonesia berada pada peringkat sepuluh negara dengan penderita DM terbanyak (usia 20-79 tahun) yaitu mencapai 7,3 juta orang. ${ }^{4}$

Meningkatnya status sosial ekonomi memicu perubahan gaya hidup dan berkurangnya aktifitas fisik. Data Riskesdas tahun 2007 menunjukkan bahwa prevalensi kurang makan buah dan sayur sebesar 93,6\%, dan prevalensi kurang aktivitas fisik pada penduduk $>10$ tahun sebesar $48,2 \%$. Disebutkan pula bahwa prevalensi merokok setiap hari pada penduduk $>10$ tahun sebesar $23,7 \%$ dan prevalensi minum beralkohol dalam satu bulan terakhir adalah $4,6 \%{ }^{4}$

Beberapa penelitian terkini, diantaranya pengaruh pemberian madu terhadap penderita diabetes dan hasil yang diperoleh bahwa dengan pemberian madu dapat menurunkan kadar glukosa darah pada penderita diabetes. Madu dapat menjadi salah satu solusi untuk mengatasi DM karena mengandung fruktosa $(38,5 \%)$, dan glukosa $(31,0 \%)$ yang berperan dalam penurunan glukosa darah. Madu juga mengandung sejumlah kecil senyawa kimiawi yang dianggap berfungsi sebagai antioksidan, anti inflamasi, antitumor, anti bakteri, dan meningkatkan sistem imun. ${ }^{5-10}$

Alwaili, dkk., memberikan madu sebanyak $75 \mathrm{~g}$ yang dilarutkan dalam $250 \mathrm{ml}$ air selama 15 hari, dapat menurunkan kadar glukosa darah penderita diabetes. ${ }^{11}$ Mohsen, dkk., memberikan madu selama delapan minggu pada pasien diabetes dan diperoleh hasil bahwa berat badan, kolesterol total, LDL, dan TGL pasien diabetes mengalami penurunan, dan HDL pasien diabetes mengalami peningkatan. ${ }^{12}$ Erujuwa, dkk., memberikan madu pada tikus diabetes dan menemukan efek hepatoprotektif dari madu. ${ }^{13}$ Penelitian ini bertujuan menilai efek pemberian madu terhadap profil lipid, gula darah puasa, tekanan darah, dan kadar Alanin Transaminase (ALT) pasien diabetes mellitus tipe 2.

\section{BAHAN DAN METODE}

Jenis penelitian yang digunakan adalah quasi experiment dengan desain pre-post control. Penelitian dilakukan pada bulan April-Juni 2014. Lokasi penelitian dilakukan di Kota Makassar. Sampel penelitian memenuhi kriteria, yaitu penderita DM tipe 2, usia 20-60 tahun, BMI $\leq 30 \mathrm{~kg} /$ $\mathrm{m}^{2}$, tidak sedang hamil atau meyusui, tidak sedang dalam terapi insulin, tidak menderita penyakit akut dan tidak sedang dalam perawatan rumah sakit. Jumlah sampel sebanyak 36 orang terbagi atas 18 orang kelompok intervensi (Kelompok I) dan 18 orang lainnya kelompok kontrol (Kelompok II). Kelompok I adalah penderita DM tipe 2 yang menerima madu sebanyak $70 \mathrm{gr} / \mathrm{hr}$ selama 4 minggu dan edukasi gizi, sedangkan Kelompok II adalah pasien DM tipe 2 yang hanya menerima edukasi gizi. Variabel penelitian terdiri dari kadar Gula Darah Puasa (GDP), tekanan darah (sistolik dan diastolik), profil lipid (total kolesterol, HDL, LDL, trgliserida), dan Alanin Transaminase (ALT). Pengukuran yang dilakukan berupa berat badan, tinggi badan, lingkar pinggang, tekanan darah, profil lipid, GDP, ALT, food recall 24 jam, dan aktivitas fisik sebelum dan setelah penelitian. Analisis data menggunakan program software SPSS. Analisis univariat digunakan untuk melihat sebaran data secara deskriptif masing-masing variabel. Uji T berpasangan (Wilcoxon) digunakan untuk menganalisis perbedaan rata-rata dua nilai yang saling berhubungan, yaitu data kadar profil lipid, GDP, tekanan darah, ALT, dan antropometri sebelum dan setelah intervensi. Uji T independen (Mann-Whitney $\mathrm{U}$ ) digunakan untuk menganalisis data perbedaan rata-rata kadar profil lipid, GDP, tekanan darah, dan ALT antara Kelompok I dan Kelompok II sebelum dan setelah penelitian. Data yang diperoleh disajikan secara naratif, grafik dan 
tabel yang dikelompokkan berdasarkan variabel yang diteliti.

\section{HASIL}

Baseline data responden yang menjadi sampel tidak berbeda secara signifikan antara kelompok intervensi yaitu usia $(\mathrm{p}=0,62)$, berat badan $(\mathrm{p}=0,26)$, IMT $(\mathrm{p}=0,30)$, gula darah puasa $(\mathrm{p}=0,25)$, total kolesterol $(\mathrm{p}=0,37), \mathrm{LDL}(\mathrm{p}=0,83)$, HDL $(p=0,81)$, trigeliserida $(p=0,96)$, tekanan darah sistolik $(\mathrm{p}=0,19)$, tekanan darah diastolik $(\mathrm{p}=0,71)$. Berdasarkan hasil analisis data pada penelitian ini diperoleh bahwa sebelum intervensi ti- dak ada variabel yang memiliki berbedaan rata-rata yang signifikan antara kelompok I dan kelompok II, kecuali variabel ALT $(\mathrm{p}=0,02)$ (Tabel 1$)$.

Pengaruh pemberian madu dan edukasi gizi pada kelompok I memberi hasil yang positif yang diperlihatkan dengan penurunan kadar GDP sebesar $55,6 \pm 24,3 \mathrm{mg} / \mathrm{dL}(\mathrm{p}=0,000)$, total kolesterol

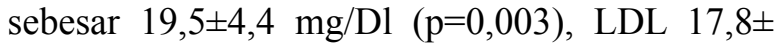
$5,2 \mathrm{mg} / \mathrm{dL}(\mathrm{p}=0,001)$, tekanan darah sistolik sebesar 5,6 $61 \mathrm{mmHg}(\mathrm{p}=0,20)$ dan diastolik sebesar $7,4 \pm 12,5 \mathrm{mmHg}(\mathrm{p}=0,01)$ serta lingkar pinggang sebesar $0,2 \pm 0,3 \mathrm{~cm}(\mathrm{p}=0,96)$ dan naiknya kadar HDL sebesar 2,5 $\pm 0,5 \mathrm{mg} / \mathrm{dL}(\mathrm{p}=0,14)$ (Tabel 2).

Tabel 1. Karakteristik Responden

\begin{tabular}{lccccc}
\hline \multirow{2}{*}{\multicolumn{1}{c}{ Variabel }} & \multicolumn{2}{c}{$\begin{array}{c}\text { Kelompok Intervensi } \\
(\mathbf{n = 1 8})\end{array}$} & \multicolumn{2}{c}{$\begin{array}{c}\text { Kelompok Kontrol } \\
(\mathbf{n = 1 8})\end{array}$} & p \\
\cline { 2 - 5 } & Mean & SD & Mean & SD & \\
\cline { 2 - 5 } & 50.67 & 6.35 & 49.83 & 6.34 & 0.62 \\
Usia (tahun) & 59.1 & 11.3 & 55.3 & 11.4 & 0.26 \\
Berat Badan (Kg) & 24.8 & 4.44 & 23.6 & 8.18 & 0.30 \\
IMT (kg/m2) & 90.1 & 9.44 & 88.1 & 9.42 & 0.48 \\
Lingkar Pinggang (cm) & 212.17 & 84.87 & 237.56 & 73.40 & 0.25 \\
GDP (mg/dL) & 235.8 & 47.13 & 233.67 & 72.57 & 0.37 \\
Total Kolesterol (mg/dL) & 151.72 & 39.85 & 153.33 & 58.25 & 0.83 \\
LDL (mg/dL) & 46.0 & 12.0 & 47.17 & 11.97 & 0.81 \\
HDL (mg/dL) & 178.3 & 73.2 & 177.8 & 89.40 & 0.96 \\
Trigliserida (mg/dL) & 133.9 & 19.12 & 1.46 & 31.67 & 0.19 \\
Tekanan Darah Sistolik (TDS) (mmHg) & 81.44 & 7.40 & 80.44 & 14.58 & 0.71 \\
Tekanan Darah Diastolik (TDD) (mmHg) & 22.83 & 15.05 & 16.06 & 7.19 & 0.02 \\
ALT (mg/dL) & & & & & \\
\hline
\end{tabular}

Sumber : Data Primer, 2014

Pengaruh edukasi gizi juga memperlihatkan hasil yang positif dengan menurunnya kadar GDP sebesar $41,4 \pm 16,7 \mathrm{mg} / \mathrm{dL}(\mathrm{p}=0,005)$, total kolesterol sebesar 9,5 $\pm 20,2 \mathrm{mg} / \mathrm{dL}(\mathrm{p}=0,23)$, LDL sebesar $21,9 \pm 22,5 \mathrm{mg} / \mathrm{dL}(\mathrm{p}=0,025)$, tekanan darah sistolik sebesar $0,7 \pm 1 \mathrm{mmHg}$ dan menaikan kadar HDL sebesar $2 \pm 1(\mathrm{p}=0,49)$. Jika dibandingkan antara kelompok I dan kelompok II tidak ada perbedaan signifikan rata-rata perubahan setelah intervensi kecuali pada variabel tekanan darah diastolik $(\mathrm{p}=0,04)($ Tabel 2).

Besarnya pengaruh pemberian madu dan edukasi gizi kepada penderita DM tipe II dapat dilihat pada Gambar 1. Pada Kelompok I memberi perubahan positif pada kadar gula darah puasa sebesar 26,2\%, kadar total kolesterol kadar LDL dan HDL masing-masing sebesar 8,3\%, 11,7\% dan $5,4 \%$, tekanan darah sistolik dan diastolik masing-masing sebesar $4,1 \%$ dan $9,1 \%$. Hasil pe- nelitian ini juga memperlihatkan bahwa pemberian madu dan edukasi gizi meningkatkan kadar trigliserida dan alanin transaminase masing-masing sebesar 1,85\% dan 3,07\%. Pada Kelompok II, edukasi gizi pada penderita DM memberi perubahan positif pada kadar gula darah puasa sebesar 17,43\%, kadar total kolesterol kadar LDL dan HDL masing-masing sebesar 4,07\%, 14,29\% dan $4,25 \%$, tekanan darah sistolik sebesar $0,48 \%$. Selain itu, pada kelompok II juga terjadi peningkatan kadar trigliserida sebesar $22,79 \%$, kadar alanin transaminase sebesar 5,62\% dan tekanan darah diastolik sebesar $1,62 \%$.

\section{PEMBAHASAN}

Hasil penelitian ini diperoleh bahwa de-ngan mengonsumsi madu 70 gram dan edukasi gizi selama empat minggu pada Kelompok I dan edukasi gizi pada Kelompok II menurunkan glukosa darah 
Tabel 2. Analisis Responden Berdasarkan Berat Badan, Lingkar Pinggang, IMT, Glukosa Darah, Profil Lipid, Tekanan Darah dan ALT Kelompok Intervensi dan Kontrol Pre dan Post test

\begin{tabular}{|c|c|c|c|c|c|c|c|c|c|}
\hline \multirow{2}{*}{ Variabel } & \multicolumn{2}{|c|}{ Kelompok Intervensi } & \multirow{2}{*}{ Selisih } & \multirow{2}{*}{$\mathbf{p}$} & \multicolumn{2}{|c|}{ Kelompok Kontrol } & \multirow{2}{*}{ Selisih } & \multirow{2}{*}{$\mathbf{p}$} & \multirow{2}{*}{$\begin{array}{c}\mathbf{p} \\
\begin{array}{c}\text { Kontrol } \\
\text { dan }\end{array} \\
\text { Intervensi) }\end{array}$} \\
\hline & Pre test & Post Test & & & Pre test & Post test & & & \\
\hline $\begin{array}{l}\text { Berat Badan } \\
(\mathrm{kg})\end{array}$ & $59.1 \pm 11.3$ & $60 \pm 9.7$ & $\uparrow 0.9 \pm 1.6$ & 0.40 & $55.3 \pm 11.4$ & $55.5 \pm 11.7$ & $\uparrow 0.2 \pm 10.3$ & 0.14 & 0.31 \\
\hline $\begin{array}{l}\text { Lingkar } \\
\text { pinggang }(\mathrm{cm})\end{array}$ & $90.1 \pm 9.4$ & $89.9 \pm 9.7$ & $\downarrow 0.2 \pm 0.3$ & 0.96 & $88.1 \pm 9.4$ & $88.3 \pm 9.5$ & $\uparrow 0.2 \pm 0.1$ & 0.21 & 0.64 \\
\hline $\operatorname{IMT}\left(\mathrm{kg} / \mathrm{m}^{2}\right)$ & $24.8 \pm 4.4$ & $25.3 \pm 3.5$ & $\uparrow 0.5 \pm 0.9$ & 0.40 & $23.6 \pm 4.1$ & $23.7 \pm 4.2$ & $\uparrow 0.1 \pm 0.1$ & 0.24 & 0.26 \\
\hline GDP (mg/dL) & $212.1 \pm 84.8$ & $156.5 \pm 60.5$ & $\downarrow 55.6 \pm 24.3$ & 0.000 & $237.5 \pm 73.4$ & $196.1 \pm 90.1$ & $\downarrow 41.4 \pm 16.7$ & 0.005 & 0.19 \\
\hline $\begin{array}{l}\text { Total Kolesterol } \\
(\mathrm{mg} / \mathrm{dL})\end{array}$ & $235.8 \pm 47.1$ & $216.3 \pm 42.7$ & $\downarrow 19.5 \pm 4.4$ & 0.003 & $233.6 \pm 72.5$ & $224.1 \pm 52.3$ & $\downarrow 9.5 \pm 20.2$ & 0.23 & 0.67 \\
\hline $\mathrm{LDL}(\mathrm{mg} / \mathrm{dL})$ & $151.7 \pm 39.8$ & $133.9 \pm 34.6$ & $\downarrow 17.8 \pm 5.2$ & 0.001 & $153.3 \pm 58.2$ & $131.4 \pm 35.7$ & $\downarrow 21.9 \pm 22.5$ & 0.025 & 0.65 \\
\hline HDL (mg/dL) & $46.0 \pm 12.0$ & $48.5 \pm 12.5$ & $\uparrow 2.5 \pm 0.5$ & 0.14 & $47.1 \pm 11.9$ & $49.1 \pm 12.9$ & $\uparrow 2 \pm 1$ & 0.49 & 0.46 \\
\hline $\begin{array}{l}\text { Trigliserida } \\
(\mathrm{mg} / \mathrm{dL})\end{array}$ & $178.3 \pm 73.2$ & $181.7 \pm 64.8$ & $\uparrow 3.3 \pm 8.4$ & 0.77 & $177.7 \pm 89.4$ & $218.2 \pm 138.3$ & $\uparrow 40.5 \pm 48.9$ & 0.177 & 0.93 \\
\hline TDS (mmHg) & $133.9 \pm 19.1$ & $128.8 \pm 18.1$ & $\downarrow 5.6 \pm 1$ & 0.20 & $146.3 \pm 31.6$ & $145.6 \pm 30.3$ & $\downarrow 0.7 \pm 1$ & 0.89 & 0.11 \\
\hline TDD (mmHg) & $81.4 \pm 7.40$ & $74.0 \pm 6.15$ & $\downarrow 7.4 \pm 12.5$ & 0.01 & $80.4 \pm 14.5$ & $81.7 \pm 12.9$ & $\uparrow 1.3 \pm 4.5$ & 0.61 & 0.04 \\
\hline $\operatorname{ALT}(\mathrm{mg} / \mathrm{dL})$ & $22.8 \pm 15.0$ & $23.5 \pm 20.1$ & $\uparrow 0.7 \pm 5.1$ & 0.95 & $16 \pm 7.1$ & $17.6 \pm 9.9$ & $\uparrow 0.9 \pm 2.8$ & 0.34 & 0.11 \\
\hline
\end{tabular}

Sumber: Data Primer, 2014

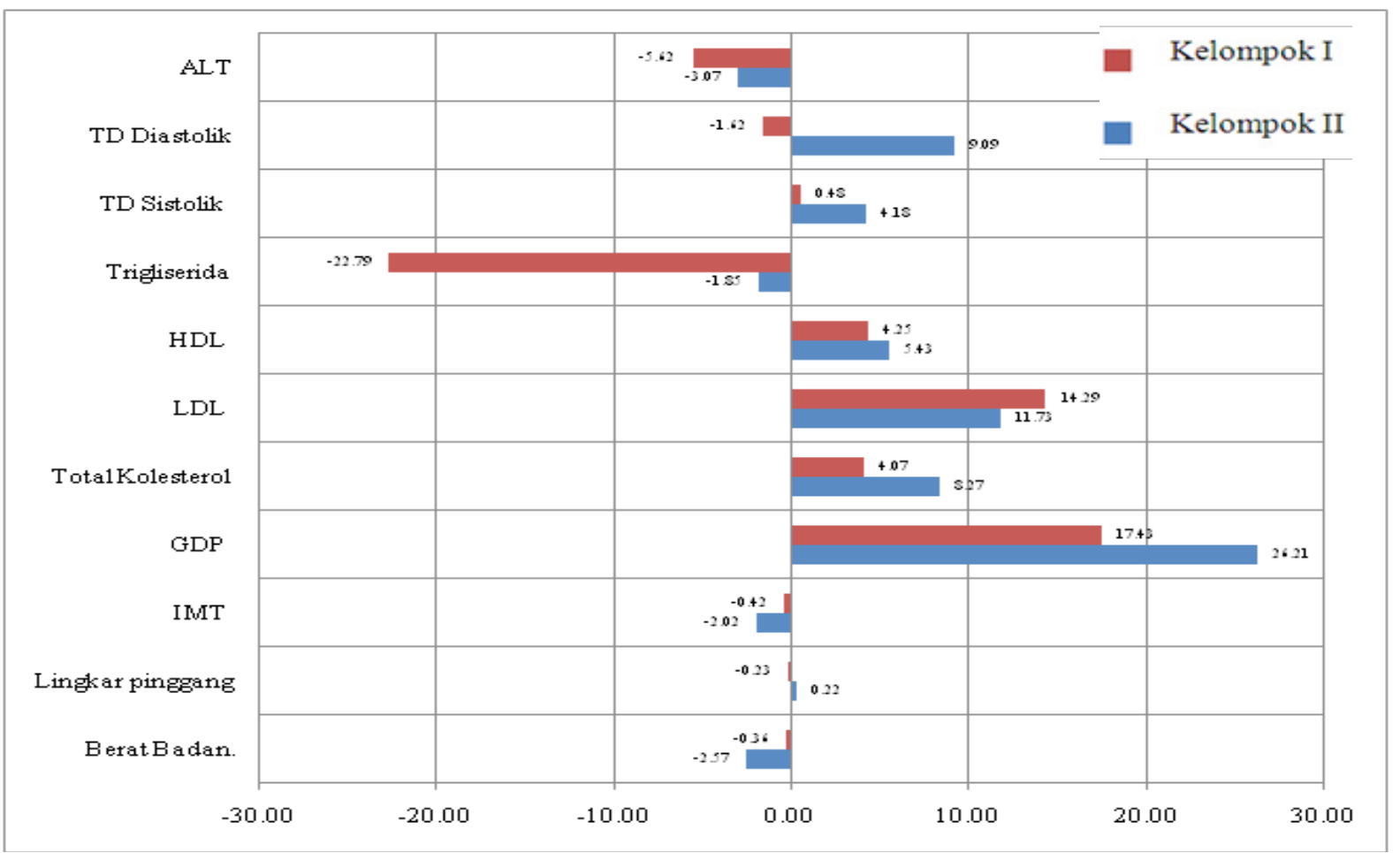

Gambar 1. Persentase Besarnya Pengaruh Intervensi Pada Kelompok I dan II

puasa secara signifikan. Penelitian Nyaghoobi, et al. diperoleh bahwa pemberian madu pada kelompok intervensi menurunkan glukosa darah puasa 4,2\%. ${ }^{14}$ Penelitian Mahmoud and Mohamed, dengan subyek diabetes melitus tipe 1, randomized crossover pilot study pada 20 pasien, kedua jenis kelamin yang berumur 4-18 tahun, pemberian madu $0,5 \mathrm{~mL} / \mathrm{kg}$ berat badan setiap hari selama 12 minggu, penurunan signifikan pada serum glukosa puasa dengan $\mathrm{p}=0,001 .^{15}$

Konsumsi fruktosa dalam jumlah sedikit mempunyai efek positif yaitu menurunkan glukosa darah melalui peningkatan uptake glukosa oleh hepar, stimulasi enzim heksokinase serta pening- 
katan konsentrasi insulin. Oleh karena itu, pada tahun 1986, HFCS digunakan sebagai gula pemanis pada penderita diabetes. Pada awal observasi, pemanis tersebut dianggap aman oleh Food and Drug Administration, akan tetapi hasil penelitian berikutnya menunjukkan asupan fruktosa lebih dari $25 \%$ kebutuhan energi per hari (sekitar $85 \mathrm{~g}$ fruktosa) menyebabkan hiper-trigliseridemia dan resistensi insulin, sehingga HFCS tidak digunakan lagi pada penderita diabetes. ${ }^{16}$ Madu adalah contoh pemanis yang kadar fruktosanya tidak terlalu tinggi, apabila disesuaikan dengan dosis per hari berdasarkan standar fruktosa pada madu, dalam $70 \mathrm{~g}$, hanya ada sekitar 26,6g. ${ }^{17,18}$

Hati memainkan peran penting dalam regulasi glukosa. ${ }^{13}$ Fruktosa pada madu juga memiliki potensi untuk memediasi efek penurunam glukosa. ${ }^{13}$ Sejumlah penelitian telah meneliti efek dari fruktosa, baik sendiri atau bersama-sama dengan glukosa, pada hewan pengerat. Dalam hepatosit terisolasi, penambahan sejumlah kecil fruktosa mengaktifkan glukokinase dan meningkatkan tingkat fosforilasi glukosa. ${ }^{13}$ Peran glukokinase hati yang menjadi perantara efek hipoglikemik fruktosa juga dikuatkan oleh beberapa penelitian. ${ }^{13}$ Pada umumnya, temuan ini menunjukkan bahwa jumlah kecil atau katalitik dosis fruktosa dapat meningkatkan penyerapan glukosa hepatik dan sintesis glikogen dan deposisi melalui aktivasi glukokinase dan enzim lain atau penghambatan beberapa enzim. ${ }^{13}$ Efek hepatik fruktosa menyebabkan toleransi glukosa membaik dan menurunkan glukosa darah. ${ }^{11,19-21}$

Kadar rata-rata total kolestrol, LDL dan HDL mengalami perubahan yang positif, baik pada Kelompok I maupun pada Kelompok II. Sebaliknya hasil yang tidak diharapkan terjadi pada kadar rata-rata trigliserida mengalami peningkatan baik pada Kelompok I dan Kelompok II. Jika dibandingkan dengan beberapa penelitian, ada beberapa kesamaan dan perbedaan penelitian diatas dengan penelitian Mohsen, dkk. memberikan madu selama delapan minggu pada pasien diabetes dan diperoleh hasil bahwa berat badan, kolesterol total, LDL, dan TGL pasien diabetes mengalami penurunan, dan HDL pasien diabetes mengalami peningkatan. ${ }^{12}$ Penelitian yang sejalan juga oleh Erejuwa melakukan penelitian bertujuan untuk melihat efek madu dengan mengkombinasikan metformin dengan glibenklamid, lamanya penelitian selama satu bulan yang diperiksa adalah kadar gula darah dan profil lipid dari hewan percobaan dan hasilnya menunjukkan bahwa konsumsi madu dengan terapi kombinasi glibenklamid maupun metformin atau kombinasi kedua-duanya dapat menurunkan glukosa darah, kolesterol total, trigliserida, LDL dan meningkatkan HDL pada tikus yang diabetes. ${ }^{22,23}$

Meningkatnya kadar trigliserida pada kedua kelompok dapat saja disebabkan oleh asupan karbohidrat meningkat pada kedua kelompok. Meskipun Kelompok I telah diberikan madu dengan antioksidannya yang secara teori dapat menurunkan trigliserida dan kolesterol, tetapi asupan karbohidrat yang tinggi dapat memengaruhi enzim antioksidan. Adjalane, et al. menunjukkan bahwa konsumsi karbohidrat tinggi menurunkan aktifitas enzim antioksidan pada tikus diabetes. ${ }^{18} \mathrm{Kadar}$ trigliserida plasma banyak dipengaruhi oleh kandungan karbohidrat dari makanan dan kegemukan. Kadar trigliserida meningkat pada pasien yang diberikan diet tinggi karbohidrat, rendah lemak dan rendah serat. Pada diabetes, risiko itu berkembang melalui suatu mekanisme yang disebut sindrom $\mathrm{X}$ atau sindrom resistensi insulin, yang terdiri dari resistensi insulin, hipertrigliseridemia, rendahnya kolesterol HDL. ${ }^{24,25}$ Risk Development in Young Adult mendapatkan bahwa konsumsi produk-produk rendah lemak dan garam disertai dengan penurunan risiko sindrom metabolik yang bermakna. Diet tinggi karbohidrat memiliki sedikit atau tidak berefek terhadap trigliserida, tetapi beberapa studi menunjukkan bahwa diet tinggi karbohidrat dapat mereduksi kadar HDL, meningkatkan kadar trigliserida dan menurunkan LDL partikel kecil. Trigliserida dibentuk di hati dari gliserol dan lemak yang berasal dari makanan dengan ransangan insulin atau kelebihan kalori akibat asupan yang berlebihan. ${ }^{24}$ Konsumsi alkohol, makanan manis, santan, dan karbohidrat secara berlebihan akan meningkatkan kadar trigliserida. ${ }^{25}$

Kelompok I, terjadi penurunan tekanan darah sistolik dan diastolik setelah pemberian madu selama 30 hari, sedangkan pada Kelompok II justru menunjukkan peningkatan tekanan darah diastolik. Hal ini sejalan dengan penelitian yang dilkukan oleh Omotayo, dkk. yang bertujuan melihat efek pemberian madu terhadap tikus yang hiperten- 
si. ${ }^{26,27}$ Hasil penelitian tersebut menemukan bahwa pemberian suplemen madu mampu menurunkan tekanan darah sistolik secara signifikan pada tikus yang mengalami hipertensi. Penelitian ini juga membuktikan mekanisme penurunan tekanan darah pada tikus yang telah diberi suplemen madu, melalui perbaikan dari stres oksidatif yang terdapat di ginjal tikus.

Hasil penelitian ini diperoleh bahwa alanin transaminase pada penderita DM pada kedua kelompok meningkat. Hal ini tidak sejalan dengan penelitian yang dilakukan oleh Erejuwa yang membuktikan bahwa pemberian madu pada tikus menurunkan secara signifikan enzim-enzim di hepar termasuk aspartat transaminase (AST), alanin transaminase (ALT) dan alkalin fofse (ALP). Begitu juga beberapa penelitian terkait lainnya yang membuktikan bahwa madu memberikan dampak positif terhadap perubahan kadar ALT di dalam hati. ${ }^{12,19,28-32}$

\section{KESIMPULAN DAN SARAN}

Pemberian madu sebanyak 70 gr per hari pada kelompok intervensi penderita DM tipe 2 menunjukkan perubahan yang signifikan terhadap kadar GDP, total kolesterol, LDL dan tekanan darah diastolik. Perbandingan antara kelompok intervensi dan kelompok kontrol hanya menunjukkan perubahan yang signifikan pada tekanan darah diastolik. Disarankan kepada penderita diabetes untuk dapat mengonsumsi madu setiap hari untuk mencegah terjadinya komplikasi.

\section{DAFTAR PUSTAKA}

1. Guariguata L, Whiting D, Hambleton I, Beagley J, Linnenkamp U, Shaw J. Global Estimates of Diabetes Prevalence for 2013 and Projections For 2035. Diabetes Research and Clinical Practice. 2014;103(2):137-149.

2. Ramachandran A, Snehalatha C, Shetty AS, Nanditha A. Trends in Prevalence of Diabetes in Asian Countries. World J Diabetes. 2012;3(6):110-117.

3. World Health Organization . Global Action Plan for The Prevention and Control of Noncommunicable Diseases 2013-2020;2013.

4. Riskesdas 2007. Riset Kesehatan Dasar 2007. Jakarta: Badan Penelitian dan Pengembangan Kesehatan Kementrian Kesehatan Republik
Indonesia;2007.

5. Han S, Lee K, Yeo J, Et Al. Effect of Honey Bee Venom on Microglial Cells Nitric Oxide and Tumor Necrosis Factor-A Production Stimulated By LPS. Journal of Ethnopharmacology. 2007;111(1):176-181.

6. Fendler A, Jung M, Stephan C, Et Al. Mirnas Can Predict Prostate Cancer Biochemical Relapse and Are Involved in Tumor Progression. International Journal of Oncology. 2011;39(5):1183-1192.

7. Van Den Berg A, Van Den Worm E, Quarles Van Ufford H, Halkes S, Hoekstra M, Beukelman C. An in Vitro Examination of The Antioxidant and Anti-Inflammatory Properties of Buckwheat Honey. Journal of Wound Care. 2008;17(4):172-179.

8. Yaghoobi R, Kazerouni A. Evidence For Clinical Use of Honey In Wound Healing As An Anti-Bacterial, Anti-Inflammatory Anti-Oxidant And Anti-Viral Agent: A Review. Jundishapur Journal of Natural Pharmaceutical Products. 2013;8(3):100-104.

9. Mohamed M, Sirajudeen K, Swamy M, Yaacob M, Sulaiman S. Studies On The Antioxidant Properties of Tualang Honey Of Malaysia. African Journal of Traditional, Complementary and Alternative Medicines. 2010;7(1).

10. Ferreira IC, Aires E, Barreira JC, Estevinho LM. Antioxidant Activity Of Portuguese Honey Samples: Different Contributions of The Entire Honey and Phenolic Extract. Food Chemistry. 2009;114(4):1438-1443.

11. Al-Waili NS, Boni NS. Natural Honey Lowers Plasma Prostaglandin Concentrations In Normal Individuals. Journal of Medicinal Food. 2003;6(2):129-133.

12. Mahesh A, Shaheetha J, Thangadurai D, Muralidhara Rao D. Protective Effect of Indian Honey on Acetaminophen Induced Oxidative Stress and Liver Toxicity In Rat. Biologia. 2009;64(6):1225-1231.

13. Erejuwa O, Sulaiman S, Wahab M, Sirajudeen K, Salleh M, Gurtu S. Hepatoprotective Effect of Tualang Honey Supplementation In Streptozotocin-Induced Diabetic Rats. International Journal of Applied Research In Natural Products. 2012;4(4):37-41.

14. Yaghoobi N, Al-Waili N, Ghayour-Mobarhan 
M, Et Al. Natural Honey and Cardiovascular Risk Factors; Effects on Blood Glucose, Cholesterol, Triacylglycerole, CRP, and Body Weight Compared With Sucrose. The Scientific World Journal. 2008;8:463-469.

15. Abdulrhman MM, El-Hefnawy MH, Aly RH, Et Al. Metabolic Effects of Honey In Type 1 Diabetes Mellitus: A Randomized Crossover Pilot Study. Journal of Medicinal Food. 2013;16(1):66-72.

16. Wild S, Roglic G, Green A, Sicree R, King H. Global Prevalence of Diabetes Estimates For The Year 2000 And Projections For 2030. Diabetes Care. 2004;27(5):1047-1053.

17. White JW, Subers MH, Schepartz AI. The Identification of Inhibine, The Antibacterial Factor In Honey, As Hydrogen Peroxide and Its Origin In A Honey Glucose-Oxidase System. Biochimica Et Biophysica Acta (BBA)-Specialized Section On Enzymological Subjects. 1963;73(1):57-70.

18. Adjlane N, Tarek E-O, Haddad N. Evaluation of Oxalic Acid Treatments Against The Mite Varroa Destructor and Secondary Effects on Honey Bees Apis Mellifera. Journal Of Arthropod-Borne Diseases. 2015.

19. Cheng N, Du B, Wang Y, Et Al. Antioxidant Properties Of Jujube Honey and Its Protective Effects Against Chronic Alcohol-Induced Liver Damage In Mice. Food \& Function. 2014;5(5):900-908.

20. Erguder BI, Kilicoglu SS, Namuslu M, Et Al. Honey Prevents Hepatic Damage Induced By Obstruction of The Common Bile Duct. World J Gastroenterol. 2008;14(23):3729-3732.

21. Al Ameen N, Musa O. Effect of Nigella Sativa and Bee Honey On Pulmonary, Hepatic and Renal Function In Sudanese In Khartoum State. J Med Plant Res. 2011;5(31):6857-6863.

22. Erejuwa OO, Sulaiman SA, Wahab M, Sirajudeen K, Salleh M, Gurtu S. Glibenclamide Or Metformin Combined With Honey Improves Glycemic Control In Streptozotocin-Induced Diabetic Rats. Int J Biol Sci. 2011;7(2):244252.

23. Erejuwa O, Sulaiman S, Wahab M, Sirajudeen KS, Salleh S, Gurtu S. Effect Of Glibenclamide Alone Versus Glibenclamide and Honey On Oxidative Stress In Pancreas Of
Streptozotocin-Induced Diabetic Rats. International Journal Of Applied Research In Natural Products. 2011;4(2):1-10.

24. Mahendra H. Gambaran Demografi dan Profil Lipid Pasien Penyakit Perlemakan Hati Non-Alkoholik Dengan Riwayat Dislipidemia Di RSUP Fatmawati Pada Tahun 2013-2014 [Skripsi]. Jakarta; Universitas Islam Negeri Syarif Hidayatullah; 2015.

25. Widiastuti E. Perbedaan Kafar Ldl-Kolesterol Metoda Direk Dengan Formula Fridewold (Pada Penderita Diabetes Melitus) [Tesis]. Semarang; Program Pendidikan Pasca Sarjana Universitas Diponegoro; 2003.

26. Erejuwa OO, Sulaiman SA, Ab Wahab MS. Honey: A Novel Antioxidant. Molecules. 2012;17(4):4400-4423.

27. Erejuwa OO, Sulaiman SA, Wahab MSA, Sirajudeen KN, Salleh MSM, Gurtu S. Differential Responses To Blood Pressure And Oxidative Stress In Streptozotocin-Induced Diabetic Wistar-Kyoto Rats And Spontaneously Hypertensive Rats: Effects Of Antioxidant (Honey) Treatment. International Journal Of Molecular Sciences. 2011;12(3):1888-1907.

28. Attia W, Gabry M, El-Shaikh K, Othman G. The Anti-Tumor Effect Of Bee Honey In Ehrlich Ascite Tumor Model Of Mice Is Coincided With Stimulation Of The Immune Cells. Egypt J Immunol. 2008;15(2):169-183.

29. El-Khayat Z, Ezzat A, Arbid M, Rasheed W, Elias T. Potential Effects Of Bee Honey And Propolis Against The Toxicity Of Ochratoxin A In Rats. Macedonian Journal Of Medical Sciences. 2009;2(4):311-318.

30. Aliyu M, Odunola OA, Owumi SE, Et Al. Daily Consumption Of Honey: Effects On Male Wister Albino Rats. International Journal Of Food And Safety. 2012;1(330):66-74.

31. Afroz R, Tanvir E, Hossain MF, Et Al. Protective Effect Of Sundarban Honey Against Acetaminophen-Induced Acute Hepatonephrotoxicity In Rats. Evidence-Based Complementary and Alternative Medicine. 2014;2014.

32. Khalil M, Sulaiman S. The Potential Role of Honey and Its Polyphenols In Preventing Heart Disease: A Review. African Journal of Traditional, Complementary and Alternative Medicines. 2010;7(4). 